\title{
RECENZJE
}

Bogdan Góralczyk

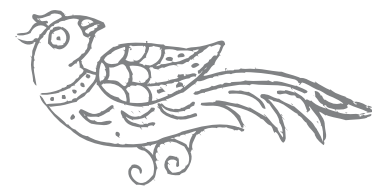

\section{WIDOK ZZA KOSZAROWYCH MURÓW}

Thant Myint-U, The River of Lost Footsteps. Histories of Burma, Farrar, Straus and Giroux, New York 2006, 363 s.

Jedno z najbardziej enigmatycznych i zamkniętych państw świata, na szeroko rozumianym Zachodzie zaliczane jest do grona dziwolagów i skostniałych dyktatur, obok Korei Północnej, Kuby czy Iranu. Związek Myanmar, szerzej znany z brytyjskiego derywatu jako Birma, nie ma dobrej prasy, a precyzyjniej w zasadzie nie ma żadnej prasy. Wiedza, co się w tym kraju dzieje, jak też co jest z nim związane, sprowadza się do kilku stereotypów: brutalna militarna junta, izolacja, nagminne łamanie praw człowieka, potworna bieda, no i jedyny jasny punkt na tej palecie, chociaż też ochlapany na ciemno zachowaniem władz - zdobywczyni pokojowej nagrody Nobla (1991 r.) Aung San Suu Kyi.

Wreszcie trafiła na rynek księgarski pozycja, którą z całą odpowiedzialnością można polecić jako przewodnik po dziejach tego ciekawego, a niemal nieznanego kraju. Autor, Birmańczyk urodzony i żyjący na stałe w Nowym Jorku, ale mający spore doświadczenie w regionie (pracował w misjach ONZ w Kambodży, przebywał i uczył się w Tajlandii) i często odwiedzający kraj przodków (jego dziadkiem był nikt inny, jak U Thant, sekretarz generalny ONZ w latach 60.), jest idealnym wprowadzającym. Zna Birmę - Myanmar od wewnątrz, ale pisze dla zachodniego czytelnika. Innymi słowy, tłumaczy birmańskie zawiłości i zaszłości czytelnikom, którzy zazwyczaj nic o tym kraju nie wiedzą. Trzeba przyznać, że wyjątkowo udany to przewodnik, napisany klarownie i zajmująco. Jeśli miałbym wybrać jedną, jedyną książkę przed wy- 
jazdem do Myanmaru, byłaby to właśnie ta, rozumiana jako osobisty esej, mówiący o dziejach tego kraju. Dlaczego tak wysoka ocena - i to już na samym wstępie?

Thant Myint-U ma dar jasnego wykładu kwestii, które wcale takie jasne nie sa, bo nie tylko kryją się w mrokach dziejów, lecz także mają słabe zaplecze archiwalne (większość birmańskich kronik była pisana na liściach palmowych, zniszczonych przez klimat, klęski żywiołowe i nagminne wojny, które autor sumiennie relacjonuje) i opisywane są w różnych wersjach, uzależnionych od pochodzenia danego autora. Birma to rzeczywiście związek wielu państw, skrystalizowanych narodów z własnymi językami, kulturami i historią (obok Birmańczyków żyją tam takie narody, jak m.in. jak Shan, Mon, Karen, Karenni czy Rakhain-Arakan), jak też niezliczonych grup etnicznych i mniejszości (wymienia się ponad sto). To była i jest etniczna oraz kulturowa mieszanka, na dodatek często ze sobą zwaśniona.

Tylko trzem władcom w dziejach udało się te ziemie, ogniem i mieczem, połączyć. Wyniosłe pomniki wszystkich trzech stoją przed Muzeum Narodowym w Rangunie (Yangonie), jak też w nowej, przeniesionej zaledwie w listopadzie 2005 r. stolicy państwa Naypidaw, w środkowej części kraju. Pierwszy z nich, Anawrahta (autor posługuje się innym derywatem jego nazwiska - Aniruddha), zjednoczył te ziemie w XI w. i rozwinął wspaniałą cywilizację Pagan (Bagan), do dziś zapierającą dech w piersiach tysiącami cudownych pagód. Jego następcy nie byli tak udani. Doszło do naturalnych i uzasadnionych podziałów. Drugie Imperium Birmańskie utworzył w XVI stuleciu król Bayinnaung, podobnie jak poprzednik - mieczem, krwią i brutalnością. Zapisał się on w historii jako zdobywca w 1569 r. syjamskiej stolicy Ajutthai (zaś północne ziemie tajskie, zwane Lanna, podobnie jak Laos, na długo zwasalizował). I wreszcie trzeci birmański heros - król Alaungphaya, twórca ostatniego Imperium w XVIII w., który też dotarł do Ajutthai, ale nie zdążył jej zdobyć i pod jej murami zmarł (syjamską stolicę zdobył w 1767 r. jego następca, niszcząc ją tak doszczętnie, że Tajowie, nie mając już czego odbudowywać, przenieśli ją w 1782 r. do Bangkoku).

Autor w swoim historycznym eseju, przypominającym świetne pisarstwo naszego Pawła Jasienicy, umiejętnie porusza się po zawiłościach birmańskich dziejów, w których zmieniały się nie tylko dynastie i rządzące konstelacje, ale też stolice, będące zarazem ośrodkami władzy, gdy ziemie te nie były scalone (najczęściej nie były). Po upadku Paganu istniały w dziejach birmańskich takie centra cywilizacyjne jak Ava (na północy, w pobliżu Mandalay), Pegu (Bago; nieopodal Rangunu), Prome i Toungoo w środkowej części kraju, czy Moulmein-Martaban na ziemiach Monów w pobliżu Tajlandii, na południu. Dodajmy do tego, że ziemie Shanów, w północno-wschodniej części kraju, częściej były niezależne niż podległe jakiemukolwiek centrum, a nad Zatoką Bengalską przez wieki dominowało samodzielne Królewstwo Arakan (ruiny dawnej jego stolicy Mrauk-U jeszcze czekają na odkrycie i masowego turystę), a dopiero wówczas otrzymamy wyobrażenie skomplikowanych dziejów tych ziem. Prawda jest bowiem taka, że okrzyczane Mandalay było stolicą państwa zaledwie kilka 
dekad w XIX w., a Brytyjczycy, zgodnie zresztą z tutejszą tradycją, iż każda nowa dynastia zakładała własną stolicę, przenieśli centrum władzy do Rangunu.

Trzy wojny z Brytyjczykami $(1822-24 ; 1852 ; 1885)$ i utrata niepodległości na rzecz kolonizatorów zajmują w omawianej pracy poczesne miejsce. Opisane są niezwykle barwnie, podobnie jak zmierzch birmańskiej państwowości i upadek ostatnich, nieudanych królów, rezydujących w Mandalay (ostatni władca Thibaw zmarł na wygnaniu w Indiach). Mandalay spłonęło, a skarby wywieźli Brytyjczycy i tylko część, w tym słynny tron królewski (dziś wystawiony w Muzeum Narodowym w Rangunie), zwrócił po II wojnie światowej lord Mountbatten.

Podstawowy zrąb pracy stanowią jednak rozdziały dotyczące XX w. i jego konsekwencji dla czasów obecnych. Thant Myint-U wnikliwie zagłębia się w początki ruchu niepodległościowego w państwie, ściśle powiązanego z ruchem nacjonalistycznym (nurt komunistyczny był słabszy, choć chwilami też wpływowy). Opisuje, jak na Uniwersytecie w Rangunie młodzież utworzyła grupy, z których wyrośli przyszli przywódcy i władcy państwa. Najważniejsza z nich to tzw. 30 Towarzyszy, którzy naznaczyli dalsze dzieje kraju. Jeden z nich, Aung San, postawił na współprace z Japończykami, gdy ci dokonali w 1942 r. inwazji, ale później nie miał skrupułów i zmienił szyki, traktując niepodległość jako dzieło święte (jego pierwsza akcja przeciwko Japończykom dokonana 27 marca 1945 r. do dziś jest Dniem Armii). Awansował na generała, jest traktowany jako twórca niepodległości i narodowy bohater. Nie doczekał tej niepodległości, ogłoszonej za radą wszechmocnych astrologów o 4.20 nad ranem 4 stycznia $1948 \mathrm{r}$. Zginął w lipcu poprzedniego roku z rąk najemników, nasłanych przez jednego z rywali. Zostawił żonę z trójką małych dzieci. Jeden z synów zginął młodo w wypadku, drugi jest inżynierem w San Diego w Kalifornii, a najmłodsza córka to nikt inny, jak Aung San Suu Kyi.

Spróbujmy streścić, jak autor widzi najnowsze dzieje Birmy, czyli Myanmaru (tę ostatnią nazwę, odwołując się - nie bez uzasadnienia - do pradziejów, wprowadziła wojskowa junta w latach 90. minionego stulecia; autor stroni od jej używania, bo też nie jest na zewnątrz szeroko przyjęta). Po ogłoszeniu niepodległości premierem został inny z 30 Towarzyszy, buddysta z przekonań (nigdy nie żył w przepychu), radosny i przyjazny z natury, utopijny, mało dyplomatyczny i niezbyt pragmatyczny w zachowaniach $\mathrm{U} \mathrm{Nu}$. Jest traktowany przez autora, ale chyba i przez cały naród, z wyraźna rewerencją. Może nie był arcywzorem przywódcy, ale był wyrazista, demokratyczną z przekonań osobowością. Nie dążył do bezwzględnej, dyktatorskiej władzy, co go w dziejach Birmy zdecydowanie wyróżniało. Miał za to wybitnych doradców. Wśród nich kolejnego z 30 Towarzyszy, U Thanta, który w 1955 r. był jednym z sekretarzy słynnej Konferencji w Bandungu (państw postkolonialnych, z których wkrótce potem wyłonił się ruch państw niezaanagażowanych). Nie można jednak twierdzić, że sympatyczny i barwny U Nu był efektywnym przywódca. W 1958 r. kolejny z 30 Towarzyszy (i ostatni, który wpłynął na dzieje państwa), twórca i niepodzielny władca armii po śmierci Aung Sanga, generał Ne Win, wykorzystując społeczne niezadowo- 
lenie dokonał zamachu stanu. Wprowadził rządy tymczasowe, które - jak pisze autor - wedlug wszelkich ocen byty najbardziej efektywne $i$ wydajne w nowoczesnych dziejach Birmy. Byty one jednocześnie rzq̨dami twardej ręki, czasami wręcz brutalnej. Te tymczasowe rządy trwały ponad dwa lata, do grudnia 1960 r., kiedy wybory ponownie wygrał, z dużą przewagą, popularny w narodzie $\mathrm{U} \mathrm{Nu}$. Ne Win, przyzwyczajony do niepodzielnej władzy, dokonał 2 marca 1962 r. kolejnego wojskowego zamachu. Wtedy zainicjował politykę, której skutki można odczuć do dziś dnia. Birma została zamknięta dla zewnętrznego świata. Samoloty linii Air France, KLM, Panam, Northwest $\mathrm{i}$ innych firm, które latały przez Rangun do całego regionu, zostały usunięte. $\mathrm{Na}$ pewien czas pozostało jedynie połączenie z Bangkokiem (do dziś jest niewiele lepiej, lotnisko Mingaladon w Rangunie należy do najsenniejszych stołecznych aerodromów na całym świecie). Na podstawie dwóch dosyć mętnych, niemal orwellowskich dokumentów, ogłoszono „birmańską drogę do socjalizmu”. Zagraniczne firmy i fundacje, głównie amerykańskie, wypędzono z kraju, zastopowano rynek, a całą władzę oddano wojsku. Pierwszy rzq̨d wojskowy (po 1958 r. - B.G.) zwrócit się do technokratów, urzędników stużby cywilnej, przedstawicieli środowiska akademickiego i innych, by efektywnie i sprawnie wykonywali swoja prace. Ten nowy rzad wojskowy byt doktadnym zaprzeczeniem poprzedniego, wyróżniajac się intensywnym brakiem zaufania do fachowców, wyjaśnia autor.

Ne Win - playboy, tyran i przekonany wyznawca astrologii - zdobył niepodzielną władzę, a Birma straciła lata 60., jak pisze autor. Okazuje się, że nie tylko te lata, następne dekady również. Do poważniejszych rozruchów za jego rządów twardej ręki doszło jedynie w 1973 r. podczas pogrzebu U Thanta, który Thant Myint-U opisuje wyjątkowo barwnie (sam był wówczas jako 8-latek po raz pierwszy w kraju rodziców i przodków). Do żadnej zmiany nie doszło, spodziewano się jednak, że nastąpi ona po śmierci Ne Wina. Na próżno. Zmarł w spokoju w grudniu 2002 r. w wieku 91 lat. To prawda, że wcześniej, zresztą w zaskakujący sposób, oddał władzę, najprawdopodobniej za radą astrologów, reagując na rosnące niezadowolenie na stołecznych uczelniach, głównie Politechnice i Uniwersytecie. 23 lipca 1988 r. zwołał nadzwyczajne posiedzenie Komitetu Centralnego Birmańskiej Partii Socjalistycznej Drogi (jedynej partii, jaka po 1962 r. istniała) i ku zdumieniu zgromadzonych wezwał do narodowego referendum na rzecz powrotu do demokracji. Nastapiła sekwencja wydarzeń, świetnie opisana przez autora już w jednym ze wstępnych rozdziałów, mówiącym także o upadku monarchii. Cały ten epizod można z powodzeniem nazwać birmańską wersją głośnej masakry na placu Tiananmen w Pekinie wiosną następnego roku. W sierpniu 1988 r. studenci w Rangunie, którzy poważnie wzięli zapewnienia dyktatora i uwierzyli przedwcześnie w demokrację, ginęli falami pod naporem wojska (nikt nie wie, ilu naprawdę wówczas straciło życie). Wydarzenia zakończyła prawdziwa masakra w dniach 18-20 września, dokonana przez wojska dowodzone przez samego szefa armii, generała Saw Maunga. 
Uprzedziły jąjednak wydarzenia, które okazały się nie bez znaczenia dla przyszłości kraju. W Rangunie, nieco przez przypadek, ze względów rodzinnych, przebywała po wieloletniej nieobecności Aung San Suu Kyi - córka bohatera narodowego, „twórcy niepodległości", generała Aung Sanga (którego mauzoleum u stóp słynnej pagody Shwedagon, centrum buddyzmu w kraju, jest po dziś dzień szczelnie zamknięte i strzeżone przez żołnierzy). Namówiona, nie bez trudu, przez przyjaciół, 25 sierpnia po raz pierwszy wystapiła na masowym wiecu. Natychmiast zdobyła serca zebranych. Przy wsparciu generała Aung Gyi, który w 1962 r. walnie przyczynił się do udanego zamachu Ne Wina, lecz potem popadł w niełaskę, oraz niegdysiejszego szefa sztabu armii, generała Tin Oo, który trafił na parę lat do aresztu za rzekomą próbę zamachu stanu, a także innych wojskowych oraz intelektualistów wykształconych na Zachodzie, powołano do życia Narodową Ligę na rzecz Demokracji (NLD) - masowy ruch, który szybko przekształcił się w partię opozycyjną wobec systemu.

Po krwawym stłumieniu studenckiej rewolty generał Ne Win odsunął się w cień (czynił to jednak powoli, chcąc sobie zabezpieczyć spokojną starość, co mu się udało), a faktyczną władzę przejęła Państwowa Rada Przywrócenia Prawa i Porządku (State Law and Order Restoration Council, SLORC), czyli wojskowa junta, na tyle pewna siebie, że po stłumieniu studenckich rozruchów dążyła do powszechnych wyborów, zapowiedzianych przez Ne Wina. Doszło do nich w maju 1990 r., a wygrała je z ogromną przewagą NLD. Kiedy 28 lipca NLD wezwała wojskowych do uznania wyników wyborów i ustapienia, generałowie ze SLORC rozpoczęli aresztowania, nie pomijając Aung San Suu Kyi. Chociaż 2 lata później junta zmieniła nazwę na Państwową Radę Pokoju i Rozwoju (State Peace and Deveopment Council, SPDC), a na jej czele stanął (i stoi do dziś) generał - senior (,,starszy generał”) Than Shwe, Związek Myanmar wpadł w pułapkę, zamieniając się w przykładowy wzorzec „państwa upadłego" (failed state). Rządzi nim nadal twardą ręką wojskowa junta, opozycja nie ma prawa głosu, Aung San Suu Kyi spędziła 11 z ostatnich 17 lat w więzieniach i odosobnieniu (od maja 2003 r. w areszcie domowym). Kraj trwa nadal w izolacji (chociaż niepełnej, bo swą szansę zwietrzyli tu Chińczycy, o czym jednak autor, a szkoda, szerzej nie pisze) i pogrąża się w gospodarczym marazmie. Co więcej, na jego obrzeżach nieprzerwanie trwają konflikty, włącznie z tym, uznanym za najdłużej trwający na świecie, bo od końca II wojny światowej, z Karenami na pograniczu z Tajlandią (w mniejszym stopniu z mniejszościami Wa i Mon). Dzisiejsza Birma - Myanmar w powszechnej opinii świata to gospodarcza, moralna, polityczna i humanitarna katastrofa. Jednakże rządzący generałowie uważają inaczej. I dalej brną w ślepy zaułek, jaki stworzyli całemu społeczeństwu.

Co na ten temat sądzi autor? Warto zacytować jego wnioski, bo wybiegają poza standardowe opinie na temat Birmy i jej historii. Przede wszystkim, zwraca on uwagę, że wojskowych w Birmie nie będzie można nagle „wrzucić do lamusa” (przypomnijmy, kto stanął wokół Aung San Suu Kyi, gdy ta tworzyła NLD!), bo prawdę powiedziawszy, armia jest jedyną sprawnie funkcjonującą instytucją w tym kraju, a elit 
wykształconych na Zachodzie już niestety w Myanmarze nie ma. Wszelkie inne instytucje zostały przez armię zdominowane lub zniszczone. Izolacja zniszczyła instytucje i zastawiła pułapkę, pisze autor, a następnie wyjaśnia: Polityka izolacji jednego z najbardziej izolowanych państw świata ... jest mało efektywna, a zarazem groźna... Każde przejście do demokracji jest trudne. W wielu punktach na globie próby przejścia od dyktatury do demokracji wywoływaty wiele nowych problemów, wtaczajac $w$ to uzycie przemocy pomiędzy grupami etnicznymi $i$ wojnę domowa. Transformacja Birmy będzie szczególnie trudna. To jest kraj, w którym już od 60 lat toczy się wojna domowa i to taka, która nie została zakończona; to kraj, gdzie wspótistnieje ze soba setki etnicznych i jezzykowych grup, wiele spośród których zamieszkuje odległe, górzyste tereny; gdzie bieda jest endemiczna, a kryzys humanitarny jest w petnym rozkwicie; gdzie setki tysięcy ludzi zostało wyrzuconych ze swych domów przez toczqce się walki, a tysiqce innych zamieniło się w uchodźców.... Dodatkowo, uzasadnia autor, wbrew szerzej przyjętym teoriom, nawet trzy wielkie Imperia Birmańskie nie były przykładami państw sukcesu, a jeśli już, to w sensie bardziej militarnym, niż cywilizacyjnym lub ekonomicznym. Historia Birmy to dtugie dzieje budowy państwa upadtego. Ostatni królowie w XIX w., Midon i Thibaw, usiłowali wprowadzić reformy, ale im się to nie udało. Brytyjczycy przejęli kraj zdewastowany niezliczonymi wojnami, także domowymi, i zacofany. System, jaki narzucili, na wzór radżów w Indiach, też się na tych ziemiach nie przyjął, bo był sztuczny i obcy. A potem przyszły kolejne wojny i dyktatury...

Birma - Myanmar ma ciekawa, choć burzliwą i tragiczną historię, która jest nie tylko u nas, ale także na całym Zachodzie dość słabo i powierzchownie znana. Dominują stereotypy oraz próby narzucania naszych pojęć na tamtejsze realia. Mówiąc o demokratycznej drodze dla tego kraju - jak się powszechnie domagamy - warto pamiętać, że tak naprawdę ten złożony twór żadnych większych demokratycznych doświadczeń nie posiada. Ma za sobą natomiast wiele tragedii i przelewu krwi. Nie ma żadnych wątpliwości, że zasługuje na lepszy los niż ten, który mu w czasie ostatnich dekad przypada. Nie ma też najmniejszych wątpliwości, że rządy w tym kraju są złe i okrutne. Jednakże domagając się, jakże słusznie, nowych, należy poznać tamtejsze skomplikowane realia. Albowiem nie znając ich, można narodom, zamieszkałym w Związku Myanmar, zapewnić kolejny etap tworzenia „upadłego państwa”. Omawiana książka, barwna i ciekawa, choć tragiczna w wymowie, przed takim właśnie scenariuszem nas przestrzega. Zanim wydamy własne sądy, warto więcej wiedzieć. A chcąc więcej wiedzieć o Birmie, warto zacząć właśnie od tej pozycji. 